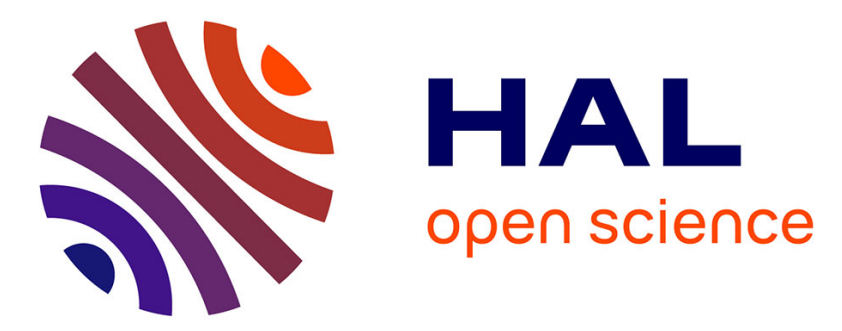

\title{
Effects of naphthalene and phenanthrene on visual and prey capture endpoints during early stages of the dourado
}

Paulo S. M. Carvalho, Daniel Da Costa B. Kalil, Gabriel A. A. Novelli, Afonso C. D. Bainy, Ana Paula M. Fraga

\section{To cite this version:}

Paulo S. M. Carvalho, Daniel Da Costa B. Kalil, Gabriel A. A. Novelli, Afonso C. D. Bainy, Ana Paula M. Fraga. Effects of naphthalene and phenanthrene on visual and prey capture endpoints during early stages of the dourado. Marine Environmental Research, 2008, 66 (1), pp.205. 10.1016/j.marenvres.2008.02.059 . hal-00563023

\section{HAL Id: hal-00563023 https://hal.science/hal-00563023}

Submitted on 4 Feb 2011

HAL is a multi-disciplinary open access archive for the deposit and dissemination of scientific research documents, whether they are published or not. The documents may come from teaching and research institutions in France or abroad, or from public or private research centers.
L'archive ouverte pluridisciplinaire HAL, est destinée au dépôt et à la diffusion de documents scientifiques de niveau recherche, publiés ou non, émanant des établissements d'enseignement et de recherche français ou étrangers, des laboratoires publics ou privés. 


\section{Accepted Manuscript}

Effects of naphthalene and phenanthrene on visual and prey capture endpoints during early stages of the dourado Salminus Brasiliensis

Paulo S. M. Carvalho, Daniel da Costa B. Kalil, Gabriel A. A. Novelli, Afonso C. D. Bainy, Ana Paula M. Fraga

PII: S0141-1136(08)00088-3

DOI: 10.1016/j.marenvres.2008.02.059

Reference: MERE 3234

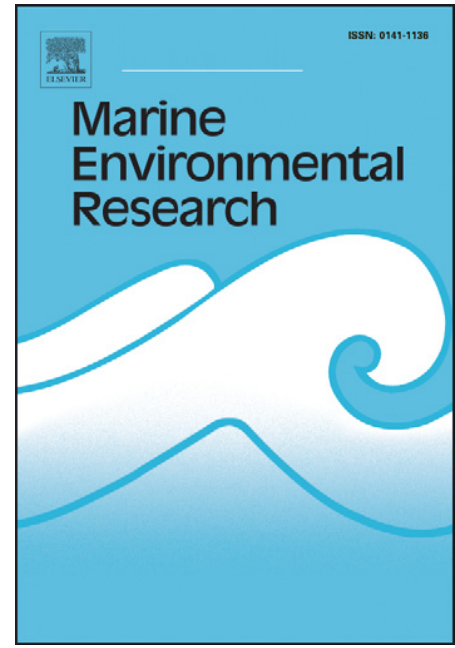

To appear in:

Marine Environmental Research

Please cite this article as: M. Carvalho, P.S., Costa B. Kalil, D.d., A. Novelli, G.A., D. Bainy, A.C., M. Fraga, A.P., Effects of naphthalene and phenanthrene on visual and prey capture endpoints during early stages of the dourado Salminus Brasiliensis, Marine Environmental Research (2008), doi: 10.1016/j.marenvres.2008.02.059

This is a PDF file of an unedited manuscript that has been accepted for publication. As a service to our customers we are providing this early version of the manuscript. The manuscript will undergo copyediting, typesetting, and review of the resulting proof before it is published in its final form. Please note that during the production process errors may be discovered which could affect the content, and all legal disclaimers that apply to the journal pertain. 


\title{
Effects of naphthalene and phenanthrene on visual and prey capture endpoints during early stages of the dourado Salminus Brasiliensis
}

\author{
Paulo S. M. Carvalho a,", Daniel da Costa B. Kalil ${ }^{\text {b }}$, Gabriel A. A. \\ Novelli ${ }^{\text {b }}$, Afonso C. D. Bainy ${ }^{\text {b }}$, Ana Paula M. Fraga ${ }^{\text {b }}$ \\ ${ }^{a}$ Department of Zoology, Universidade Federal de Pernambuco, 50670-420 Recife, PE, Brazil \\ ${ }^{b}$ Department of Biochemistry, Universidade Federal de Santa Catarina, 88040-900, Florianópolis, \\ SC, Brazil.
}

\begin{abstract}
Naphthalene (NAP) and Phenanthrene (PHE) effects on Salminus brasiliensis, a carnivorous freshwater fish, were investigated using behavioral tests. Larval stages of $S$. brasiliensis were exposed to water concentrations of $0,0.04 \mathrm{mg} / \mathrm{L}, 0.20 \mathrm{mg} / \mathrm{L} \mathrm{e}$ $0.50 \mathrm{mg} / \mathrm{L}$ for naphthalene and $0,0.01 \mathrm{mg} / \mathrm{L}, 0.05 \mathrm{mg} / \mathrm{L} \mathrm{e} 0.1 \mathrm{mg} / \mathrm{L}$ for phenanthrene during two developmental phases. The prey fish Prochilodus lineatus were not exposed. Visual acuity was measured at the end of phase 2 in individual $S$. brasiliensis, which were also tested at the end of each phase for number of attacks on prey, number of prey captured, prey capture efficiency, and distance swam. Vision was impaired by PHE exposure, as acuity angles increased in exposed fish. At Stage I $2.3 \pm 1.2$ prey were captured with $46 \%$ efficiency in controls compared to $0.4 \pm 0.3$ prey
\end{abstract}


captured with $13.4 \%$ efficiency in fish exposed to 0.05 mgPHE. ${ }^{-1}$, the LOEL for both endpoints. At Stage II 4.0 \pm 1.1 preys were captured in controls compared to $2.5 \pm 0.9$ preys captured in fish exposed to $0.01 \mathrm{mgPHE} . \mathrm{l}^{-1}$, the LOEL. Stage II control fish captured prey with $70 \%$ efficiency compared to $30 \%$ efficiency at Stage II fish exposed to $0.05 \mathrm{mg}$ PHE. $\mathrm{I}^{-1}$, the LOEL. Distance swam was not affected by either NAP or PHE exposure. The exposure of larval stages of S. brasiliensis to realistic water concentrations of PHE impairs foraging skills and could affect recruitment of the species.

Keywords: PAHs; phenantrene; vision; foraging behavior; early life stage; fish

*Corresponding Author: Tel.: +55-81-34591549; fax: +55-81-21238353

Email address: pcarvalho@ufpe.br (P.M.S. Carvalho)

The freshwater fish Salminus brasiliensis (dourado) is a voracious predator of other fishes that is highly valued both ecologically and economically in Brazil. Naphthalene (NAP) and phenantrene (PHE) are among the major PAHs present in crude oil transported through inland oil pipelines in Brazil, and have been identified in concentrations similar to the ones used in this study after an accident in Iguaçu River (Meniconi and Gabardo, 2002), a tributary of Paraná River, within the distribution range of the dourado. Early life stages of fish tend to be the most sensitive to contaminants, and behavioral tests using these stages are needed to link suborganismal effects to population level effects (Scott et al. 2004). Visual skills are critical for larval fish to capture prey, a process related to growth, survival, and 
recruitment to the adult population. Here we further evaluate an interesting model relating possible visual impairment and consequent ecologically relevant effects during fish early life stages (Carvalho et al., 2004). Larvae of Salminus brasiliensis and curimba Prochilodus lineatus were obtained from a local fish research laboratory (LAPAD-UFSC) and kept in $15 \mathrm{~L}$ aquariums at a temperature of $25 \pm 0.5{ }^{\circ} \mathrm{C}$ during the experiments that lasted 12 days. Larval dourado start exogenous feeding at the $2^{\text {nd }}$ day after hatch (DAH), and they were fed larval fish Prochilodus lineatus (total length of $6 \mathrm{~mm})$ at a rate of approximately 5 prey.fish.day ${ }^{-1}$. Seven treatment groups of 25 larval dourados were each exposed to control water and water concentrations of 0.04 $\mathrm{mg} / \mathrm{L}, 0.20 \mathrm{mg} / \mathrm{L}$ e $0.50 \mathrm{mg} / \mathrm{L}$ for naphthalene and $0.01 \mathrm{mg} / \mathrm{L}, 0.05 \mathrm{mg} / \mathrm{L}$ e $0.1 \mathrm{mg} / \mathrm{L}$ for phenanthrene during two developmental phases: from $2^{\text {nd }}$ to $5^{\text {th }}$ day after hatch (DAH) (Stage I), and from $6^{\text {th }}$ to $10^{\text {th }}$ DAH (Stage II). Visual acuity of individual dourado were measured from 8 to $10 \mathrm{DAH}$ based on their optokinetic behavior using an optomotor system (Carvalho et al., 2002). At the end of Stage I (day 6) and end of Stage II (day 10), a suite of foraging behavior parameters were measured in 12 individual fish from each treatment group. At each experimental run, seven fish were individually tested simultaneously (one from each treatment group) in seven separate arenas $(14.5 \mathrm{~cm} \times 11 \mathrm{~cm})$ monitored by CFTV cameras connected to a Geovision computer card at 30 frames per second. Each foraging trial consisted of $12 \mathrm{~min}$, starting at the moment preys were simultaneously offered to all seven fish being tested. At the end of test, uneaten prey were counted, fish were removed from the arenas, measured, weighted, and returned to the exposure aquarium. Each individual video was analyzed and the following parameters were quantified: total number of attacks to prey, total number of prey captured, and prey capture efficiency (total attacks/total captures). Linear distance swam by individual fish was quantified by 
counting the number of squares crossed by the fish snout in 20 equal squares in the test arena. Results and variability for all measurements are expressed as mean \pm S.D. Statistically significant differences between control and NAP exposed $S$. brasiliensis were not detected for any of the endpoints measured in NAP exposed fish. Vision was impaired by phenantrene exposure, as acuity angles increased from 2.4 degrees \pm 0.8 in controls to 3.3 degrees \pm 0.6 at $0.05 \mathrm{mgPHE} . \mathrm{l}^{-1}$, the lowest observed effect level (LOEL) $(\mathrm{p}<0.05$; Anova followed by Dunnett's test). Prey capture abilities were impaired in phenanthrene exposed fish. At Stage I, out of $6.8 \pm 4.4$ attacks, $2.3 \pm 1.2$ prey were captured with $46 \%$ efficiency in controls compared to a total of 4.8 attacks and $0.4 \pm 0.3$ prey captured with $13.4 \%$ efficiency in fish exposed to 0.05 mgPHE. $1^{-1}$, the LOEL for all of these 3 endpoints $(p<0.05$, ANOVA followed by Dunnet's test). At $0.1 \mathrm{mg} / \mathrm{L}$ PHE a prey capture efficiency of $2.3 \%$ out of 2.9 attacks in average was achieved (Figure 1). Control fish at Stage II attacked 6.1 times and captured $4.0 \pm 1.1$ prey, compared to $2.5 \pm 0.9$ prey captured in fish exposed to 0.01 mgPHE. ${ }^{-1}$, the LOEL ( $<<0.05$, Anova followed by Dunnet's test). Stage II control fish captured prey with $70 \%$ efficiency compared to $30 \%$ efficiency at Stage II fish exposed to $0.05 \mathrm{mg}$ PHE. $\mathrm{l}^{-1}$, the LOEL ( $\mathrm{p}<0.05$, Anova followed by Dunnet's test). It is interesting to note that number of attacks at Stage II was not affected by PHE exposure, indicating that exposed fish were active and searching for prey. The visual acuity deficits detected at the two highest PHE exposure treatments succesfully predicted the decrease in foraging skills exhibited by PHE exposed dourados during their first 10 days of life. The linear distance swam by the dourados during the foraging experiments was not affected by either NAP or PHE exposure. The search volume model of fish foraging behavior (Blaxter, 1971) takes into account vision and motor swimming as major components of the prey capture behavioral sequence. Our 
data indicate that swimming behavior was not affected by PHE exposure, and suggests that visual impairment of PHE exposed fish could be the major ecological mechanism of effect. The behavioral parameters measured in this study can be applied in recruitment models, enabling the prediction of fish early life stage survival (Letcher et al., 1996).

\section{Acknowledgements}

We would like to thank Marcos Weingartner and Evoy Zaniboni (LAPAD) for kindly providing the larval fish used in this study. ACDB is recipient of CNPq productivity fellowship. This research was supported by grants from CTPetro-CNPq (500213-2002-0) and International Foundation for Science Grant W3632-1.

\section{References}

Blaxter, J. H. S., and Staines, M. (1971). In: Crisp, D. J., Ed. Fourth European Marine Biology Symposium. (pp. 467-485). Cambridge University Press, Cambridge.

Carvalho, P.S.M., Noltie, D.B., and Tillitt, D.E. (2002). Animal Behaviour, 64, 1-10.

Carvalho, P. S. M.; and Tillitt, D. E. (2004). Environmental Science and Technology, 38, 6300-6306.

Letcher, B.H., Rice, J.A., Crowder, L.B., and Rose, K.A. (1996). Canadian Journal of Fisheries and Aquatic Sciences, 53, 787-801.

Meniconi, M.F.G., and Gabardo, I.T. (2002). Environmental Forensics, 3, 303-321.

Scott, G.R., and Sloman, K.A. (2004). Aquatic Toxicology, 68, 369-392. 
Figure caption

Fig. 1. Number of attacks, number of prey captured and capture efficiency of Salminus brasiliensis larvae at Stage I (6days after hatch) and Stage II (10 days after hatch). *:statistically significant difference compared with control, alfa $=5 \%$; error bars: standard deviation
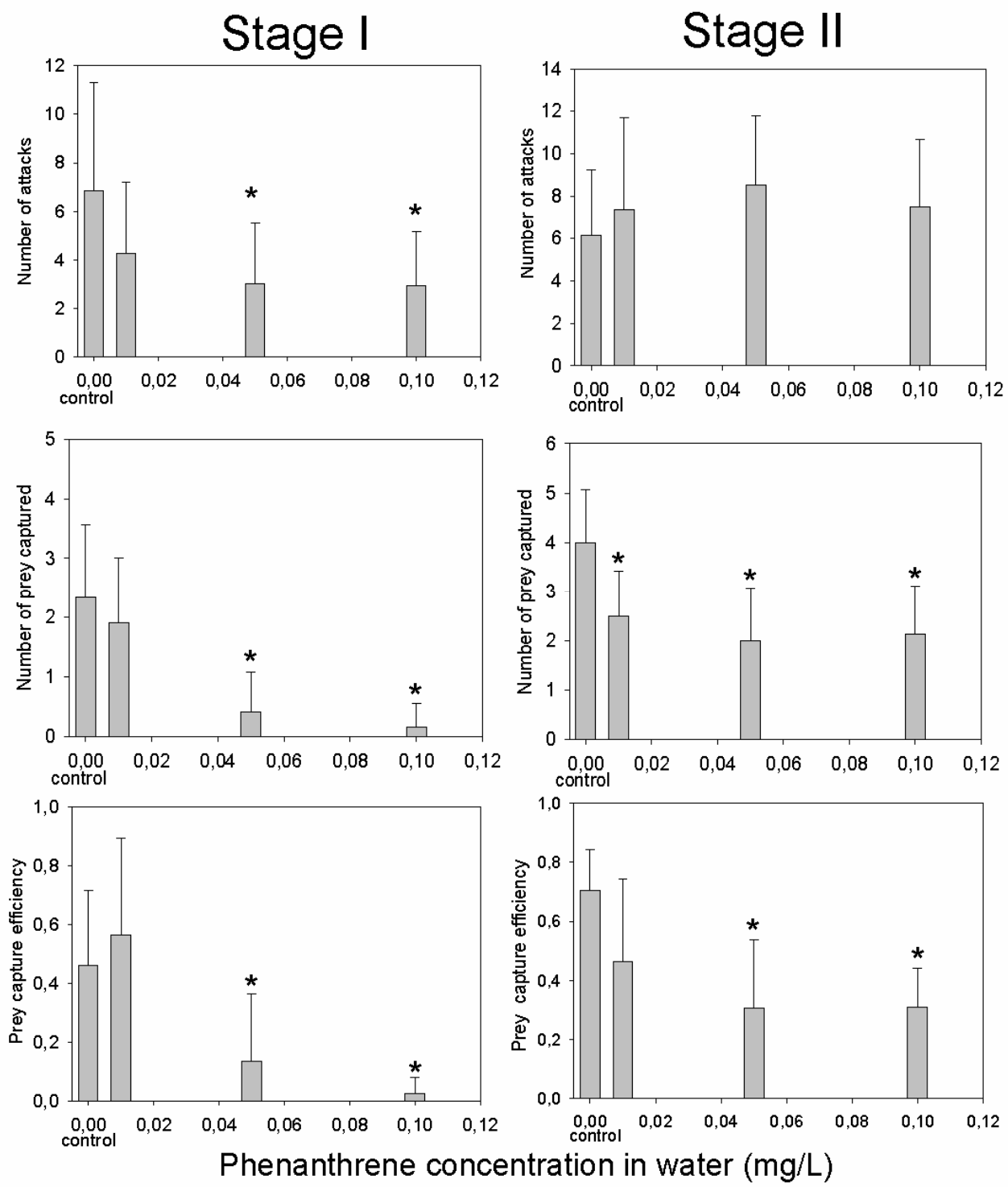